\title{
Contributions of phototrophic and heterotrophic nutrition to the metabolic and growth requirements of four species of giant clam (Tridacnidae)
}

\author{
D. W. Klumpp ${ }^{1}$, C. L. Griffiths ${ }^{2}$ \\ ${ }^{1}$ Australian Institute of Marine Science, PMB 3, Townsville MC, Australia 4810 \\ ${ }^{2}$ Zoology Department, University of Cape Town, Rondebosch 7700, South Africa
}

\begin{abstract}
We compare the relative contributions of phototrophy (translocation of photosynthates from zooxanthellae) and heterotrophy (filtered particles) towards the carbon requirements for tissue and shell growth, and metabolism in 4 species of giant clam from the Great Barrier Reef. The primary aims were to determine whether the differences in growth rates of various clam species could be due to nutrition, and to quantify the relative roles of phototrophy and heterotrophy in the nutrition of tridacnids. The species examined were distinguishable by both absolute $\mathrm{C}$ flux and relative proportions of components of the $\mathrm{C}$ budget. For example, Tridacna gigas was photosynthetically the most efficient. gaining twice as much nutrition as $T$. crocea, and an order of magnitude more than Hippopus hippopus. In the case of the smallest clams tested $(0.1 \mathrm{~g}$ tissue $\mathrm{wt}$ ), intake of $\mathrm{C}$ via filter feeding was also highest in $T$. gigas, being 10 times that of the other species. These interspecific differences declined with clam size. Tridacna gigas, $T$. crocea, and $T$ squamosa were able to satisfy all their growth and metabolic requirements from the intake of photosynthate and particulate food, in some cases with considerable energy to spare. In contrast, small $H$. hippopus gained $80 \%$ of total $\mathrm{C}$ needs from these sources. We confirm that phototrophy is the most significant source of energy to clams. In all but the smallest $H$. hippopus, this source provides sufficient $C$ for growth and metabolic requirements. Filterfeeding decreases in importance with increasing size of clam. Ingested C provides 61 to $113 \%$ of total needs in 40 to $80 \mathrm{~mm}$ T. gigas and 36 to $44 \%$ in H. hippopus, but was less significant to the other species (10 to $20 \%)$. H. hippopus allocated the highest proportion of $\mathrm{C}$ expenditure to growth (30 to $90 \%)$, up to half of which went into shell. T. gigas and T. squamosa both put 20 to $40 \%$ of $\mathrm{C}$ into growth, compared with only 10 to $20 \%$ in $T$. crocea. There was no simple nutritional basis to the differences in growth of the 4 species. T. gigas has the greatest excess of energy available for growth, and the highest growth rate in terms of shell length. However, the connection between available energy and growth rate was not consistent across species. Actual growth in units of $\mathrm{C}$ was similar in $T$ gigas and $H$. hippopus, yet small individuals of the latter species appear limited by availability of C. Despite a relatively high calculated 'scope' for growth, $T$. crocea exhibited the lowest growth rate possibly because its growth is limited by physical constraints of its burrowing habit.
\end{abstract}

KEY WORDS: Giant clam · Tridacnid - Symbiosis · Filter-feeding · Growth - Carbon budget · Coral reef

\section{INTRODUCTION}

The giant clam family, Tridacnidae, contains 9 living species, 2 in the genus Hippopus and 7 Tridacna species. Giant clams colonise coral-reef environments throughout the Indo-Pacific region, where they are widely exploited. Because of the declining populations in many regions, brought about by over-fishing for shell and meat, giant clams are now the subjects of an international mariculture exercise (Fitt 1993a, Lucas in press). The need to develop the methodology for culturing giant clams has stimulated a major increase in research into their biology, including aspects of their nutrition (Fitt 1993a).

The present study contributed to this knowledge by comparing the nutrition of 4 species of clam from the Great Barrier Reef (GBR); Tridacna gigas, T. crocea, T. squamosa and Hippopus hippopus. These species 
occupy a wide range of coral-reef habitats (Lucas 1988). Intertidal reef flats in nearshore areas are the characteristic habitat of both $H$. hippopus and $T$ crocea, whereas $T$. gigas and $T$. squamosa are more common subtidally ( 5 to $15 \mathrm{~m}$ ) on offshore reefs. $T$. crocea is often found in high densities, and always deeply embedded into the surface of coral boulders, while $H$. hippopus lives unattached on sandy and rocky substrata. $T$. gigas spans a wide range of habitats, from inshorereef flats where waters are relatively turbid, to the lagoons and slopes of outer reefs down to $15 \mathrm{~m}$ depth.

On the basis of growth rates and maximum sizes (Hamner \& Jones 1976, Shelley 1989, Pearson \& Munro 1991, Lucas in press) these species can be divided into 3 main groups: Tridacna crocea is the smallest and slowest growing (shell length up to $15 \mathrm{~cm}$ ), T. squamosa and Hippopus hippopus are intermediate in growth and size (up to $40 \mathrm{~cm}$ ), and an order of magnitude lighter than the gigantic $T$. gigas, the largest and fastest growing of all bivalve molluscs (largest recorded specimen $137 \mathrm{~cm}$ ). Lucas (in press) discusses these differences in a recent, comprehensive review of the biology and mariculture of giant clams, and raises the question 'Why do some species grow more rapidly?'. He points out that the answer to this question is currently limited by a lack of information on the nutrition of large clams, particularly of species other than $T$. gigas.

It is now established that photosynthates fixed by symbiotic zooxanthellae are able to provide sufficient energy to cover at least the metabolic needs of Tridacna gigas (Fisher et al. 1985, Mingoa 1988, Klumpp et al. 1992), T. squamosa (Trench et al. 1981), T. derasa and $T$. tevoroa (Klumpp \& Lucas 1994). Only recently, however, have efforts been made to assess overall energy acquisition (photosynthesis plus filter feeding) and compare this with total requirements (respiration plus growth). Klumpp et al. (1992) showed that T. gigas can grow much faster than typical non-symbiotic bivalves because it is able to allocate a relatively high proportion of its energy expenditure to growth. This in turn is a function of the ability of this species to utilise both phototrophic and heterotrophic sources of nutrition. More recently, Hawkins \& Klumpp (in press) demonstrated further energy conservation, via a relatively high food absorption efficiency, and the capacity of the algal symbionts in $T$. gigas to recycle inorganic nitrogen normally lost to bivalves during excretion.

The possibility that there is a nutritional basis to the differential growth rates of giant clam species prompted this study, which aims to compare nutrition of a wide size-range of individuals from 4 clam species displaying markedly different growth rates. We also seek to assess the role of filter-feeding as an energy source in giant clams, generally. The growth-rate dif- ferences between species investigated cannot simply be attributed to environmental conditions, since the same interspecific patterns of growth are observed in groups of clams growing together under the controlled and ideal conditions of mariculture (Crawford et al. 1988, Gomez \& Belda 1988).

Thus as a first step, we compared the above 4 species maintained under controlled conditions, with levels of irradiance and particulate food simulating the reefflat at Orpheus Island (site of James Cook University Research Station). For each species, we calculated uptake of carbon derived from photosynthesis (measured oxygen production) and filter feeding and the simultaneous metabolic energy expenditure (respiration rate). Incorporations of carbon into growth of tissues and shell are estimated from published data on linear growth and our measurements of the carbon content of both flesh and shell.

\section{MATERIALS AND METHODS}

Collection and maintenance of clams. The Tridacna gigas used in this study were cultured specimens originating from the mariculture unit of the Orpheus Island Research Station, North Queensland, Australia. Hippopus hippopus and $T$. crocea were collected from wild stocks colonising intertidal fringing reefs at Iris Point and Pioneer Bay, Orpheus Island (18 $37^{\prime} \mathrm{S}, 146^{\circ} 30^{\prime} \mathrm{E}$ ), respectively. $T$. squamosa were collected from 1 to $10 \mathrm{~m}$ depth at Davies Reef (18 $50^{\prime} \mathrm{S}, 147^{\circ} 38^{\prime} \mathrm{E}$ ) on the Great Barrier Reef. All clams were transferred to the outdoor, flow-through seawater system at the Australian Institute of Marine Science, where they were acclimated for at least $3 \mathrm{wk}$ in $2 \times 1 \mathrm{~m}$ tanks of $0.5 \mathrm{~m}$ water depth. The tanks were roofed with shadecloth (50\%) and water temperature varied from approximately 24 to $27^{\circ} \mathrm{C}$ over the study period (early summer). The shells of all clams were thoroughly cleaned of epibionts during the acclimation period, using a knife and wire brush, and were re-cleaned with a scrubbing brush the day before use in each of the following experiments.

Respirometry. The primary objectives of these experiments were to record night respiration rates $(R)$ and gross photosynthetic rate $(P)$-irradiance $(I)$ relationships for a size range of clams from each species. A data-logging respirometer, the technical details of which are described by Klumpp et al. (1987), was utilised. This respirometer was capable of monitoring irradiance and temperature, as well as the oxygen concentrations in each of 4 replicate chambers, at $1 \mathrm{~min}$ intervals for up to $24 \mathrm{~h}$. The water in each chamber was automatically flushed every 15 min and chamber volumes could be varied from 2 to 57 I to accommodate. clams of a wide size range. 
The respirometer was immersed in a $0.5 \mathrm{~m}$ deep 1000 l capacity outdoor tank exposed to a natural daylight cycle and supplied with running seawater. The protocol used was to run one set of clams from noon to approximately 23:00 h and a second group from 23:00 h until noon the following day. In this way each group was exposed to a full range of natural light intensities, as well as to several hours of darkness.

$P$-I relationships were modelled using the hyperbolic tangent function (see Chalker 1981), $P=$ $P_{\max } \tanh \left(I / I_{k}\right)$, where $P_{\max }$ is the asymptote, and $I_{k}$ is the irradiance at which the initial slope of the $P$-I plot $(\alpha)$ intersects $P_{\max }$. The irradiance at which gross $P$ and $R$ are equal is the compensation point $\left(I_{C}\right)$.

Daily gross oxygen production $\left(P_{\mathrm{g}}\right)$ in 4 sizes $(0.1,1.0$, 10 and $100 \mathrm{~g}$ tissue dry wt) and species of clam was calculated by solving for $P$ in the above $P$-I function, using our empirical data on $P_{\max }$ and $I_{k}$ for a given size and species of clam. Values of $I$ were derived from long-term in situ records for Great Barrier Reef waters on cloudless days in early summer (Klumpp \& McKinnon unpubl.), and averaged over 15 min periods of the diel cycle. These data were adjusted to represent a level of $I$ expected at $0.5 \mathrm{~m}$ depth on a reef flat, i.e. $5 \%$ reduction in surface irradiance, thus approximating the experimental conditions in this study. The total oxygen consumed by the 4 size categories of clams (zooxanthellae and host) over $24 \mathrm{~h}\left(R_{24 \mathrm{~h}}\right)$ was calculated from $R$, assuming that this remains constant over $24 \mathrm{~h}$.

The percent contribution of carbon fixed by zooxanthellae to the clam's respiratory requirements, or CZAR (see Muscatine et al. 1981, Trench et al. 1981), was calculated using the formula:

$$
\begin{aligned}
& \mathrm{CZAR}= \\
& \frac{\left[\left(P_{\mathrm{q}} \times P Q \times 0.375\right)-\left(R_{24 \mathrm{~h}} \times R Q \times 0.375\right)(0.05)\right] \times(\% T) \times 100}{R_{24 \mathrm{~h}} \times R Q \times 0.375 \times 0.95}
\end{aligned}
$$

The numerator in this equation is the amount of photosynthate carbon transferred daily to the host ( TP as

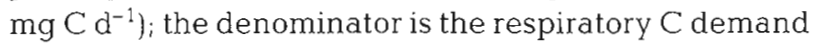
of the clam host $\left(R_{\mathrm{H}}\right.$ in $\left.\mathrm{mgC} \mathrm{d} \mathrm{d}^{-1}\right)$. It was assumed that $1 \mathrm{mg} \mathrm{O} 2=0.375 \mathrm{mg} \mathrm{C}, \mathrm{RQ}=0.8, \mathrm{PQ}=1.0$, host $R$ was $95 \%$ of the measured entire clam $R$ with the balance due to zooxanthellae (Klumpp et al. 1992), and that $95 \%$ of excess photosynthate produced by algal symbionts was translocated to the host ( $\% T$ ). Much lower values for $\% T$ (30 to $40 \%$ ), based on in vivo $\mathrm{C}^{14}$-uptake experiments (e.g. Trench 1979, Griffiths \& Streamer 1988), have been used in the past when making similar calculations for giant clams (Fitt et al. 1986, Klumpp et al. 1992). Although there is a need for more empirical data on the translocation of photosynthates in giant clams, recent research on carbon budgets in reef corals show that the translocation process is indeed highly efficient (90 to $100 \%$; Davies 1991, Gattuso et al. 1993, review by Muscatine 1990).
Clearance rates. The volume of water each clam cleared of particulate material $\left(C R, 1 \mathrm{~h}^{-1}\right)$ was determined using a flow-through system, in which seawater containing natural particles at ambient concentrations was allowed to run through sets of 4 chambers. Three of these contained a clam, while the fourth acted as a control. From the rate of flow $\left(F, l \mathrm{~h}^{-1}\right)$ and the concentration of particles leaving each experimental chamber $\left(C_{0}\right)$ and the control chamber $\left(C_{1}\right)$, clearance rates were calculated from the expression:

$$
C R=\frac{F\left(C_{1}-C_{0}\right)}{C_{0}}
$$

In this system, $C_{0}$ was the best approximation to the concentration immediately surrounding the clam, which is the correct denominator in the formula devised by Hildreth \& Crisp (1976) (see also Klumpp et al. 1992, Klumpp \& Lucas 1994). Three sets of chambers with volumes of 2, 18 and 54 l were used to hold clams of different sizes. Concentrations of particles within the size range 3 to $54 \mu \mathrm{m}$ were measured (mean of 3 counts) using a model TA II Coulter Counter with a $140 \mu \mathrm{m}$ orifice tube. Further details on the operation of the flow-through system and $C R$ determinations are given in Klumpp \& Lucas (1994). On a few occasions in which difficulties were encountered with this method, due to either low ambient particle concentrations, or slow clearance rates, the chambers were also spiked with low concentrations (100 to 1000 cells $\mathrm{ml}^{-1}$ ) of Dunaliella tertiolecta. The flow was then closed off and clearance rates calculated from the rate of decline in particle concentration, according to the appropriate standard formula:

$$
C R=\frac{\log _{e} N_{1}-\log _{e} N_{2}}{T} V
$$

where $N_{1}$ and $N_{2}$ are initial and final particle counts, $V$ the volume of the chamber (1) and $T$ the time elapsed (h).

Ingested ration for the 4 size categories of clams (IR, $\mathrm{mgC}^{-1}$ ) were calculated as the product of $C R$ (from $C R$-size regression equations) and the mean particulate organic carbon concentration in waters from reef flats in the Orpheus Island region, monitored over a $2 \mathrm{yr}$ period (mean $=200 \pm 15 \mu \mathrm{gC} \mathrm{l}^{-2}$, $\mathrm{n}=31$, range $=162$ to 242 ; Klumpp unpubl.). This compares with a range of 195 to $230 \mu_{\mathrm{gC}} \mathrm{l}^{-1}$ in waters around Lizard Island, another fringing reef on the Great Barrier Reef (Crossland \& Barnes 1983). It is assumed that all particles cleared from the water are ingested, given that clams did not produce pseudofaeces in this or previous studies (Klumpp et al. 1992, Klumpp \& Lucas 1994). Absorbed ration $\left(A R, \mathrm{mgC} \mathrm{d}^{-1}\right)$ was then the product of $I R$ and $\mathrm{ab}$ sorption efficiency (see below). 
Absorption efficiencies. The percentage of food eaten which was absorbed by the clam's digestive system was determined by comparing the fraction of faeces lost on ashing with that of samples of food suspension treated the same way. Absorption efficiency $(A E, \%)$ was then calculated according to the equation of Conover (1966):

$$
A E=\frac{f-e}{(1-e) f} \times 100
$$

where $f$ and $e$ are the fractions of food and faeces lost on ashing respectively.

Measurements of $A E$ were carried out simultaneously with those of $C R$ (see above). Faeces was collected from clams, which had been held overnight in flow-through chambers supplied with natural sea water, and were filtered onto pre-ashed GFC filter papers, rinsed with distilled water and dried and ashed at $450^{\circ} \mathrm{C}$ for $5 \mathrm{~h}$. Food samples consisted of $2 \mathrm{l}$ samples of water removed from the control chamber and were treated in the same way.

Morphometrics and growth. Rates of oxygen flux and particle clearance for each experimental individual were standardised to dry weight of tissue, which was calculated from shell length using the length-tissue weight relationships in Table 1 . To derive these relationships, selected experimental clams across a wide size range were sacrificed. The flesh was removed and drained for $15 \mathrm{~min}$ to obtain wet weights. The bodies were then cut into pieces and dried at $60^{\circ} \mathrm{C}$ to obtain dry mass. Organic carbon content of tissues and shells of selected specimens was measured by the method of Sandstrom et al. (1986).

Growth in giant clams is initially slow, then rapid and nearly linear over several years, after which there is a significant slowing in growth. The present study

Table 1. Tridacna spp., Hippopus hippopus. Comparative morphometric relationships $\left(Y=a X^{b}\right)$ for 4 species of giant clam, where $X$ is shell length $(\mathrm{mm}), Y$ is mass of shell or tissue ( $g$ dry weight)

\begin{tabular}{|llcccc|}
\hline Species & $Y$ & \multicolumn{1}{c}{$a$} & $b$ & $\mathrm{r}^{2}$ & $\mathrm{n}$ \\
\hline T. gigas & Shell & $4.76 \times 10^{-5}$ & 3.11 & 0.99 & $68^{\mathrm{a}}$ \\
& Tissue & $3.40 \times 10^{-7}$ & 3.36 & 0.99 & $77^{b}$ \\
$T$ crocea & Shell & $2.05 \times 10^{-5}$ & 3.51 & 0.99 & 16 \\
& Tissue & $3.23 \times 10^{-6}$ & 3.24 & 0.94 & 16 \\
$T$ T. squamosa & Shell & $7.19 \times 10^{-6}$ & 3.52 & 0.99 & 14 \\
& Tissue & $1.17 \times 10^{-7}$ & 3.65 & 0.98 & 14 \\
H. hippopus & Shell & $1.85 \times 10^{-4}$ & 3.02 & 0.97 & 14 \\
& Tissue & $2.97 \times 10^{-7}$ & 3.46 & 0.98 & 14 \\
a Combined data of present study and Barker et al. (1988) \\
${ }^{b}$ From Klumpp et al. (1992) \\
\hline \multicolumn{7}{|l}{}
\end{tabular}

looked at clams in the size range that basically relates to this second (rapid) phase of growth. Daily rates of deposition of organic carbon into shell and somatic tissues for the 4 size categories and species of giant clam were derived from a summary of published increments in shell length. Growth in shell length was then converted to growth of shell and somatic tissue mass using our data on shell and tissue morphometric relationships (Table 1), and of organic C content of shells and tissues.

The supply of carbon to the host via photosynthesis and filter feeding and its utilisation for respiration and growth in the different species of clam were calculated for each of 4 size classes between 0.1 and $100 \mathrm{~g}$ tissue dry weight, as described above. Larger clams were measured in the present study (150 to $250 \mathrm{~g}$ for Tridacna gigas, T. squamosa and Hippopus hippopus), but these would be sexually mature (Shelley 1989, Pearson \& Munro 1991). At this stage it is not possible to confidently quantify the reproductive process in terms of energy balance. Reproductive output was thus not considered here. However, it is known that a significant decline in linear growth rate corresponds with the onset of sexual maturity (see review by Lucas in press). This is undoubtably a function of diversion of energy to reproduction, since as much as 35 to $40 \%$ of tissue weight can be lost at spawning in T. crocea and H. hippopus (Shelley \& Southgate 1988).

Data analysis. Regression analysis showed that $C R$, $P_{\max }$ and $R$ varied markedly with clam size; thus variations in these parameters in relation to species were examined using ANCOVA, with clam size as the covariate. Means of parameters for each of the 4 species were then compared using step-wise ANCOVA and a significance level of $\mathrm{p}<0.01$. $I_{k}$ and $I_{c}$ were independent of clam size (regression analysis), thus the effect of species on these parameters was tested using 1 -way ANOVA. Where differences were significant $(p<0.05)$, means were compared using the Ryan-Einot-GabrielWelsh test. Statistical analyses were performed using SAS (1985).

\section{RESULTS}

\section{Photosynthesis-irradiance relationships and respiration}

The 4 species of giant clam differed significantly in their ability to utilise light for photosynthesis, as demonstrated by the $P$-I response curves for individuals of $1 \mathrm{~g}$ tissue dry weight shown in Fig. 1. Only Tridacna gigas and Hippopus hippopus had significantly different $I_{k}$ values (ANOVA, $p<0.05$; Table 2), but $P_{\max }$ values for $1 \mathrm{~g}$ individuals differed significantly (ANCOVA, p $<0.01$; Table 3 ) between all 4 spe- 


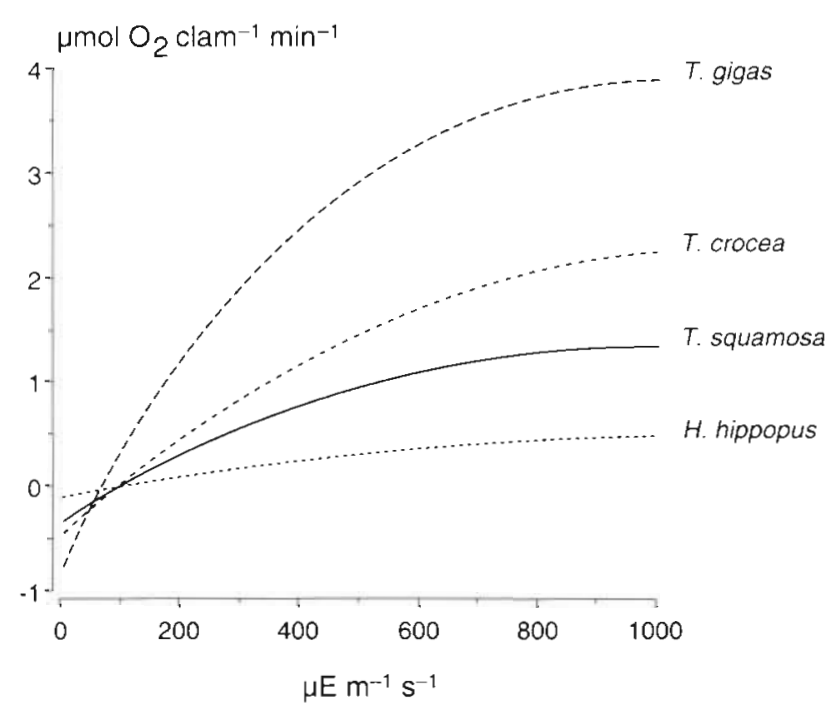

Fig. 1. Tridacna spp., Hippopus hippopus. Net oxygen flux as a function of irradiance ( $P$ - $I$ curves) for 4 species of giant clam at a size of $1 \mathrm{~g}$ tissue dry weight. Curves fitted using the hyperbolic tangent function

cies. The most efficient species photosynthetically was $T$. gigas, as it had the lowest $I_{k}\left(488 \mu \mathrm{E} \mathrm{m}^{-2} \mathrm{~s}^{-1}\right.$; Table 2$)$, the highest $P_{\max }\left(4.826 \mu \mathrm{mol} \mathrm{O} \mathrm{min}^{-1} \mathrm{~g}^{-1}\right.$; Table 3$)$, and hence the highest $\alpha\left(P_{\max } / I_{k}\right)$ of $0.01 \mu \mathrm{mol} \mathrm{O} \mathrm{min}^{-1} \mathrm{~g}^{-1}$ produced per $\mu \mathrm{E} \mathrm{m} \mathrm{m}^{-2} \mathrm{~s}^{-1}$. The least photosynthetically efficient species at this size was $H$. hippopus with the lowest $P_{\max }$ of $0.648 \mu \mathrm{mol} \mathrm{O} \mathrm{min}^{-1} \mathrm{~g}^{-1}$ and the highest $I_{k}$ of $723 \mu \mathrm{E} \mathrm{m}^{-2} \mathrm{~s}^{-1}$; thus $\alpha$ was one tenth that of $T$. gigas. Intermediate photosynthetic efficiencies were found for $T$. crocea and $T$. squamosa. Compensation irradiance did not differ significantly between the 4 species, and averaged around $100 \mu \mathrm{E} \mathrm{m}^{-2} \mathrm{~s}^{-1}$ (Table 2).

In all 4 species $P_{\max }$ and $R$ were strongly correlated with clam size (Fig. 2; Table 3), while $I_{k}$ did not vary significantly with size of any species (Regression Analysis). Slopes of the regressions of $P_{\max }$ and $R$ on size were the same within each species (Table 3 ), indicating that the ratio $P_{\max }: R$ remained constant across the size range. Exponents of these relationships for Tridacna gigas and $T$. crocea were equal at ca 0.6 to 0.7 and were significantly lower (ANCOVA) than those for $T$. squamosa and Hippopus hippopus (ca 0.9 to 1.1). As a result, the variable rates of maximum photosynthesis and respiration between species described above (and shown in Fig. 1) for small clams $(1 \mathrm{~g})$ diminished with increasing clam size such that $100 \mathrm{~g}$ individuals of $T$. gigas, $T$. squamosa and $H$. hippopus had similar $P_{\max }\left(\sim 120 \mu \mathrm{mol} \mathrm{O}_{2} \mathrm{~min}^{-1}\right)$ and $R$ $\left(\sim 14\right.$ to $\left.16 \mu \mathrm{mol} \mathrm{O}_{2} \mathrm{~min}^{-1}\right)$. T. crocea does not attain this body mass, although extra-
Table 2. Tridacna spp., Hippopus hippopus. Levels of irradiance (means and standard errors; $\mu \mathrm{E} \mathrm{m}^{-2} \mathrm{~s}^{-1}$ ) at which gross photosynthetic rates approach saturation $\left(I_{k}\right)$, or are in balance with respiration $\left(I_{c}\right)$ in 4 species of giant clam

\begin{tabular}{|lccc|}
\cline { 2 - 4 } Species & $I_{k}$ & $I_{c}$ & $\mathrm{n}$ \\
\hline T. gigas & $488 \pm 51$ & $67 \pm 5$ & 34 \\
T. crocea & $644 \pm 35$ & $91 \pm 4$ & 34 \\
T. squamosa & $535 \pm 76$ & $120 \pm 18$ & 22 \\
H. hippopus & $723 \pm 75$ & $85 \pm 7$ & 20 \\
\hline
\end{tabular}

polation to this size indicates considerably lower rates of both $P_{\max }$ and $R$ compared with the other species.

Large differences in the daily gross oxygen production $\left(P_{\mathrm{g}}\right)$ and consumption $\left(R_{24 h}\right)$ occurred between species, especially amongst smaller individuals ( 0.1 to $10 \mathrm{~g}$ tissue weight). The general order of metabolic rate across this size range was Tridacna gigas $>T$. crocea $>$ T. squamosa > Hippopus hippopus (Table 4). T. gigas produced and consumed oxygen at twice the rate of $T$. crocea over the entire size range tested, and the $0.1 \mathrm{~g} T$. gigas were 4 and 20 times more productive $\left(P_{g}\right)$ than $T$. squamosa and $H$. hippopus, respectively. However, differences in metabolism between these 3 species decreased with increasing size, due to differences in the slopes of the metabolic rate - size relationships described above. Thus, at $100 \mathrm{~g}$ tissue weight, daily oxygen flux in $T$. gigas and $T$. squamosa was indistinguishable, and only slightly higher than that of $H$. hippopus. In all sizes and species examined, the daily gross production of oxygen easily exceeded the amount consumed in respiration ( $P_{\mathrm{g}}: R \sim 2$ to 3$)$, and in all species except $H$. hippopus the $P: R$ ratio increased with body mass.

Table 3. Tridacna spp., Hippopus hippopus. Regression equations $\left(y=a x^{b}\right)$ for the relationships between tissue dry weight $(g)$ and maximum gross photosynthetic rate $\left(P_{\max }\right)$, respiration rate $(R)$ and clearance rate $(C R)$ in 4 species of giant clam. Values with the same letter in subscript are not significantly different (ANCOVA; $p<0.01$ )

\begin{tabular}{|llcccc|}
\hline Parameter $(y)$ & Species & $a$ & $b$ & $\mathrm{r}^{2}$ & $\mathrm{n}$ \\
\hline$P_{\max }$ & T. gigas & 4.826 & $0.693_{\mathrm{c}}$ & 0.91 & 34 \\
$\left(\mu \mathrm{mol} \mathrm{O} \mathrm{clam}^{-1} \mathrm{~min}^{-1}\right)$ & T. crocea & 2.944 & $0.677_{\mathrm{c}}$ & 0.82 & 34 \\
& T. squamosa & 1.781 & $0.914_{\mathrm{d}}$ & 0.94 & 22 \\
& H. hippopus & 0.648 & $1.121_{\mathrm{d}}$ & 0.88 & 20 \\
$R$ & T. gigas & 0.789 & $0.654_{\mathrm{c}}$ & 0.93 & 34 \\
$\left(\mu \mathrm{mol} \mathrm{O}_{2} \mathrm{clam}^{-1} \mathrm{~min}^{-1}\right)$ & T. crocea & $0.455_{\mathrm{c}}$ & $0.597_{\mathrm{c}}$ & 0.82 & 34 \\
& T. squamosa & $0.362_{\mathrm{c}}$ & 0.821 & 0.95 & 22 \\
& H. hippopus & 0.077 & 1.124 & 0.93 & 20 \\
$\mathrm{CR}$ & T. gigas & 3.680 & 0.397 & 0.69 & 34 \\
$\left(\mathrm{l} \mathrm{clam}{ }^{-1} \mathrm{~h}^{-1}\right)$ & T. crocea & $0.585_{\mathrm{c}}$ & $0.905_{\mathrm{c}}$ & 0.87 & 34 \\
& T. squamosa & 0.318 & $0.964_{\mathrm{c}}$ & 0.86 & 33 \\
& H. hippopus & $0.525_{\mathrm{c}}$ & 0.743 & 0.69 & 34 \\
\hline
\end{tabular}




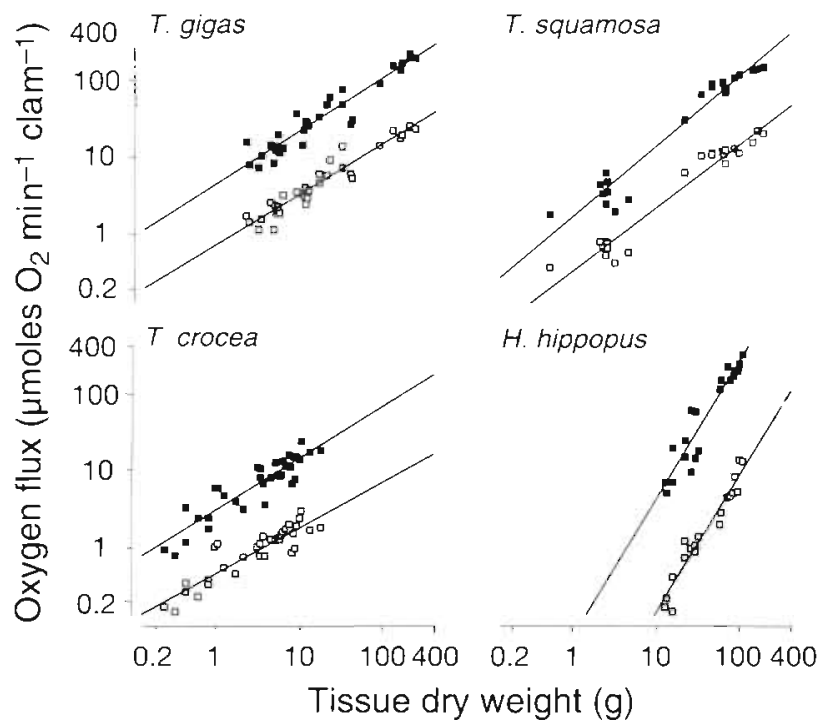

Fig. 2. Tridacna spp., Hippopus hippopus. Relationships between dry tissue weight and $(-)$ maximum rates of gross photosynthesis, and ( 0 ) respiration rates for the 4 species of clam. Each data point is the rate for a single clam. Regression equations are given in Table 3

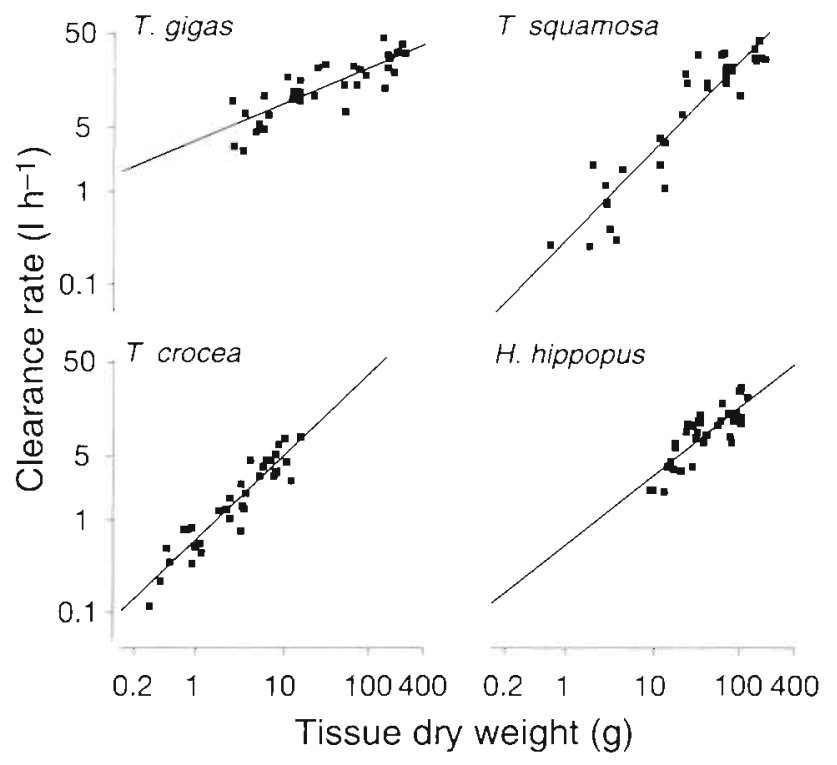

Fig. 3. Tridacna spp., Hippopus hippopus. Relationships between clearance rates and dry tissue weight for the 4 species of clam. Each data point is the rate for a single clam. Regression equations are given in Table 3

\section{Contribution of symbiotic algae to host respiratory requirements}

The absolute amounts of carbon translocated daily by the zooxanthellae to the host ( $T P$ in Table 4) follow similar patterns of variation with size and species of clam described for $P_{\mathrm{g}}$. That is, in the smaller size categories $(0.1$ to $10 \mathrm{~g}$ tissue weight) Tridacna gigas has a considerable nutri-ional advantage over the other 3 species, gaining 2 to 20 times more energy in the form of photosynthates. TP was similar in the 3 species which attain $100 \mathrm{~g}$. In all 4 species and size categories of clam, TP was well in excess of host respiratory needs $\left(R_{\mathrm{H}}\right.$ in Table 4). Calculation of the percent contribution of zooxanthellae to the host's daily carbon requirements for routine respiration (i.e. $\left.\mathrm{CZAR}=\left(T P / R_{\mathrm{H}}\right) 100\right)$, as given in Table 4, shows that symbiotic algae were capable of providing 2 to 4 times more carbon than required by the host for respiration. CZAR increased with clam size in all species, except in $H$. hippopus, which had a comparatively high and more constant CZAR of $\sim 340 \%$. The lowest CZAR value was $186 \%$ in the smallest T. squamosa.
Table 4. Tridacna spp., Hippopus hippopus. Variations with species and size of giant clam in daily gross oxygen production by zooxanthellae $\left(P_{\mathrm{g}}\right)$, oxygen consumption by the entire clam $\left(R_{24 h}\right)$, carbon translocation from zooxanthellae to host (TP), and carbon used in respiration by the host $\left(R_{\mathrm{H}}\right)$. The derivation of these parameters is described in the text. Projected data for $100 \mathrm{~g} T$ crocea are in brackets as the maximum size in the field is $\sim 40 \mathrm{~g}$

\begin{tabular}{|c|c|c|c|c|c|}
\hline \multirow{2}{*}{ Parameter } & \multirow[t]{2}{*}{ Species } & \multicolumn{4}{|c|}{ Size of clam (g tissue dry wt) } \\
\hline & & 0.1 & 1 & 10 & 100 \\
\hline \multirow{4}{*}{$\begin{array}{l}P_{g} \\
\left(\mathrm{mgO}_{2} \mathrm{clam}^{-1} \mathrm{~d}^{-1}\right)\end{array}$} & T. gigas & 17.4 & 86.2 & 420.0 & 2056.9 \\
\hline & T. crocea & 10.0 & 47.6 & 226.7 & $(1100.3)$ \\
\hline & T. squamosa & 3.8 & 31.0 & 254.8 & 2090.9 \\
\hline & H. hippopus & 0.8 & 10.0 & 132.2 & 1747.8 \\
\hline \multirow{4}{*}{$\begin{array}{l}R_{24 \mathrm{~b}} \\
\left(\mathrm{mgO}_{2} \mathrm{clam}^{-1} \mathrm{~d}^{-1}\right)\end{array}$} & T. gigas & 8.1 & 36.4 & 163.9 & 738.9 \\
\hline & $T$ crocea & 5.3 & 20.9 & 82.9 & $(327.7)$ \\
\hline & T. squamosa & 2.3 & 16.6 & 110.6 & 731.3 \\
\hline & H. hippopus & 0.3 & 3.5 & 47.2 & 628.1 \\
\hline \multirow{4}{*}{$\begin{array}{l}T P \\
\left(\mathrm{mgC} \operatorname{clam}^{-1} \mathrm{~d}^{-1}\right)\end{array}$} & $T$ gigas & 6.1 & 30.2 & 147.3 & 722.2 \\
\hline & T. crocea & 3.5 & 16.7 & 79.6 & $(387.3)$ \\
\hline & I squamosa & 1.3 & 10.8 & 89.2 & 734.5 \\
\hline & H. hippopus & 0.3 & 3.5 & 4.6 .4 & 613.7 \\
\hline \multirow{4}{*}{$\begin{array}{l}R_{H} \\
\left(m g C \operatorname{clam}^{-1} d^{-1}\right)\end{array}$} & T. gigas & 2.3 & 10.4 & 46.7 & 210.6 \\
\hline & $T$ crocea & 1.5 & 6.0 & 23.6 & $(93.4)$ \\
\hline & T. squamosa & 0.7 & 4.7 & 31.5 & 208.4 \\
\hline & H. hippopus & 0.1 & 1.0 & 13.4 & 179.0 \\
\hline \multirow{4}{*}{$\begin{array}{l}\text { CZAR } \\
\left(=T P / R_{\mathrm{H}} \times 100\right)\end{array}$} & T. gigas & 265 & 290 & 315 & 343 \\
\hline & T. crocea & 233 & 278 & 337 & $(415)$ \\
\hline & T squamosa & 186 & 230 & 283 & 352 \\
\hline & H. hippopus & 300 & 350 & 346 & 343 \\
\hline
\end{tabular}


Table 5. Tridacna spp. Hippopus hippopus. Variation with species and size of giant clam in daily clearance rate $(C R)$, ingested ration $(I R)$ and absorbed ration $(A R)$. CR was derived from the size relationships in Table 3; $I R$ is the product of $C R$ and POC in the environment $\left(200 \mu \mathrm{g} \mathrm{Cl}^{-1}\right)$ : $A R$ is the product of $I R$ and absorption efficiency as given in Table 6

\begin{tabular}{|llrrrr|}
\hline Parameter & Species & \multicolumn{4}{c}{ Size of clam (g tissue dry wt) } \\
& & 0.1 & 1 & 10 & 100 \\
\hline$C R$ & T gigas & 35.4 & 88.3 & 220.3 & 549.6 \\
$\left(\mathrm{l} \mathrm{clam}^{-1} \mathrm{~d}^{-1}\right)$ & T. crocea & 1.7 & 14.0 & 112.8 & $(906.5)$ \\
& T. squamosa & 0.8 & 7.6 & 70.2 & 646.6 \\
& H. hippopus & 2.3 & 12.6 & 69.7 & 385.8 \\
$I R$ & T. gigas & 7.1 & 17.7 & 44.1 & 109.9 \\
$\left(\mathrm{mgC} \mathrm{clam}^{-1} \mathrm{~d}^{-1}\right)$ & T. crocea & 0.3 & 2.8 & 22.6 & $(181.3)$ \\
& T. squamosa & 0.2 & 1.5 & 14.0 & 129.3 \\
& H. hippopus & 0.5 & 2.5 & 13.9 & 77.2 \\
AR & T. gigas & 3.6 & 9.0 & 22.4 & 55.8 \\
$\left(\mathrm{mgC} \mathrm{clam}^{-1} \mathrm{~d}^{-1}\right)$ & T. crocea & 0.2 & 1.5 & 12.5 & $(100.4)$ \\
& T. squamosa & 0.1 & 0.9 & 8.1 & 74.6 \\
& H. hippopus & 0.4 & 2.0 & 11.2 & 62.1 \\
\hline
\end{tabular}

size until at $100 \mathrm{~g}$ daily clearance is similar in all species. The rates at which clams ingested particles (IR in $\mathrm{mg}$ organic $C \mathrm{~d}^{-1}$ ) were then calculated as the product of $C R$ and average concentration of particulate organic carbon available on the reef flat of Orpheus Island (200 $\mathrm{MgC} \mathrm{I}^{-1}$; see 'Materials and methods' for details). For example, the smallest size category of $T$. gigas $(0.1 \mathrm{~g})$ cleared $35.4 \mathrm{l} \mathrm{d}^{-1}$, and in the process ingested $7.1 \mathrm{mgC}, 15$ to 40 times the $I R$ of the other species. This differential then declined with increasing clam size.

Ingested particulate matter was absorbed at similar efficiencies ( $A E=$ 51 to $58 \%$ ) by the 3 Tridacna species, but with a significantly higher efficiency ( $81 \%$ ) by Hippopus hippopus (Table 6 ). The resulting size-related changes in the rates of uptake of absorbed particu-

\section{Filter feeding and absorption of particulate organic matter}

All 4 species of clam cleared ambient water of particles at rates that were strongly dependent on clam body size (Fig. 3 and regression analysis in Table 3). At a weight of $1 \mathrm{~g}$ Tridacna gigas had the highest $C R$ at $3.68 \mathrm{I} \mathrm{h}^{-1}$, compared to 0.58 and $0.52 \mathrm{l} \mathrm{h}^{-1}$ for $T$. crocea and Hippopus hippopus and only $0.32 \mathrm{l} \mathrm{h}^{-1}$ for T. squamosa. Regression slopes, however, showed the reverse order, with weight-specific clearance rates increasing most rapidly in $T$. squamosa (mean 0.96), at intermediate rates in $T$. crocea and $H$. hippopus and least rapidly in $T$. gigas $(0.40)$.

Using these regression data, $C R^{\prime}$ s (in $1 \mathrm{~d}^{-1}$ ) for clams of $0.1,1,10$ and $100 \mathrm{~g}$ tissue weight were determined (Table 5). These rates differ enormously at a size of $0.1 \mathrm{~g}$, from $35.4 \mathrm{ld}^{-1}$ in $T$. gigas to only $0.8 \mathrm{ld}^{-1}$ in $T$. squamosa, but become more similar with increasing

Table 6. Tridacna spp., Hippopus hippopus. Mean ( \pm SE) absorption efficiencies $(A E)$ for different species of giant clam consuming natural particles. Data are also presented on the range in proportion of organic matter in clam faeces (e). Absorption efficiency is calculated from the formula $A E=(f-e) /((1-e) \times f)$ $\times 100$. Over the duration of these experiments (October-November), $F$ values averaged 0.56 . The mean particle concentration was $0.73 \times 10^{6}$ particles $l^{-1}$, or $2.21 \mathrm{mg}$ dry $w \mathrm{l}^{-1}( \pm 0.14 \mathrm{SE} ; \mathrm{n}=32) ;$ the range was 1.0 to $4.4 \mathrm{mg}$ dry wt $\mathrm{l}^{-1}$

\begin{tabular}{|lcccc|}
\hline Species & Size range $(\mathrm{mm})$ & $\mathrm{n}$ & $\mathrm{e}$ & $A E(\%)$ \\
\hline T. gigas & $110-427$ & 24 & $0.20-0.52$ & $50.8 \pm 2.7$ \\
T. crocea & $27-129$ & 27 & $0.23-0.52$ & $55.4 \pm 2.8$ \\
T. squamosa & $70-332$ & 17 & $0.23-0.59$ & $57.7 \pm 4.0$ \\
H. hippopus & $120-280$ & 20 & $0.14-0.28$ & $80.5 \pm 1.4$ \\
\hline
\end{tabular}

late organic $\mathrm{C}(A R=I R \times A E)$ are shown in Table 5. Of the 4 clam species, $T$. gigas gains by far the most $C$ from filter feeding except in the largest size class, by which stage it acquired least.

\section{Growth requirements}

Comparison of the morphometrics of the 4 species of clam showed only minor differences in tissue weight for a given shell length, except for Tridacna crocea which has a deeper shell and hence high tissue weight to length ratio (Table 1). For individuals of a given tissue weight, shell weight was lowest in $T$. crocea, intermediate (and similar) in T. gigas and $T$. squamosa, and heaviest in $H$. hippopus, which has a particularly thick shell. If comparing clams of the same length, then the order of shell mass would be $H$. hippopus $\geq T$. crocea $>$ $T$. gigas $=T$. squamosa $($ Table 1$)$

Published data on growth in shell length of juveniles of the 4 giant clam species have been summarised in Table 7 . There is fairly good agreement between the various estimates of growth for a given species, and the order and range in daily growth rates (in $\mathrm{mm}$ ) were: Tridacna gigas $(0.13$ to 0.37$)>$ Hippopus hippopus $(0.10$ to 0.21$) \geq T$. squamosa $(0.05$ to 0.14$)>T$. crocea $(0.01$ to 0.05$)$ Daily growth in terms of the mass (dry wt and organic $C$ ) of shell and somatic tissue for each of the 4 species and size categories, shown in Table 8, was calculated from length increments using the length- 
Table 7. Tridacna spp., Hippopus hippopus. Comparison of daily growth rates in clams as summarized from the literature. In general, these data apply to the stage prior to the point of inflection in the growth curve. which corresponds with the onset of sexual maturity. Data are presented as mean rates $\left(\mathrm{mm} \mathrm{d}^{-1}\right)$ with range in shell length to which these apply in parentheses

\begin{tabular}{|c|c|c|c|c|}
\hline Source and location & T. gigas & T. squamosa & I crocea & H. hippopus \\
\hline $\begin{array}{l}\text { Bonham (1965) } \\
\text { (Bikini Atoll) }\end{array}$ & 0.16 & & & \\
\hline $\begin{array}{l}\text { Hamner \& Jones (1976) } \\
\text { (Orpheus Is., GBR) }\end{array}$ & & & $\begin{array}{l}0.01-0.05 \\
(20-90)\end{array}$ & \\
\hline $\begin{array}{l}\text { Beckvar (1981) } \\
\text { (Palau) }\end{array}$ & $\begin{array}{l}0.22-0.33 \\
(140-240)\end{array}$ & $\begin{array}{l}0.05-0.11 \\
(130-270)\end{array}$ & & $\begin{array}{l}0.08-0.14 \\
(120-280)\end{array}$ \\
\hline $\begin{array}{l}\text { Munro \& Heslinga (1983) } \\
\text { (General review) }\end{array}$ & $\begin{array}{c}0.13-0.37 \\
(-190)\end{array}$ & $\begin{array}{c}0.13 \\
(-200)\end{array}$ & & $\begin{array}{c}0.14 \\
(-100)\end{array}$ \\
\hline $\begin{array}{l}\text { Murakoshi (1986) } \\
\text { (Okinawa) }\end{array}$ & & & $\begin{array}{c}0.04 \\
(5-65)\end{array}$ & \\
\hline $\begin{array}{l}\text { Gomez \& Belda (1988) } \\
\text { (Philippines) }\end{array}$ & $\begin{array}{c}0.23 \\
(75-125)\end{array}$ & $\begin{array}{c}0.07 \\
(12-50)\end{array}$ & & $\begin{array}{r}0.07-0.21 \\
(16-100)\end{array}$ \\
\hline $\begin{array}{l}\text { Solis et al. (1988) } \\
\text { (Philippines) }\end{array}$ & & $\begin{array}{c}0.09 \\
(0-35)\end{array}$ & & $\begin{array}{c}0.11-0.18 \\
(-105)\end{array}$ \\
\hline $\begin{array}{l}\text { Crawford et al. (1988) } \\
\text { (Orpheus Is., GBR) }\end{array}$ & $\begin{array}{c}0.18-0.19 \\
(-200)\end{array}$ & $\begin{array}{c}0.06-0.09 \\
(-100)\end{array}$ & & $\begin{array}{l}0.13 \\
(-50)\end{array}$ \\
\hline $\begin{array}{l}\text { Crawford et al. (1988) } \\
\text { (Lizard Is., GBR) }\end{array}$ & $\begin{array}{c}0.14 \\
(-150)\end{array}$ & & & $\begin{array}{c}0.10 \\
(-110)\end{array}$ \\
\hline $\begin{array}{l}\text { Barker et al. (1988) } \\
\text { (Orpheus Is., GBR) }\end{array}$ & $\begin{array}{l}0.15-0.25 \\
(30-200)\end{array}$ & & & \\
\hline $\begin{array}{l}\text { Shelley (1989) } \\
\text { (central GBR) }\end{array}$ & $\begin{array}{l}0.16-0.20 \\
(200-400)\end{array}$ & $\begin{array}{c}0.14 \\
(-250)\end{array}$ & & $\begin{array}{l}0.10-0.11 \\
(80-250)\end{array}$ \\
\hline $\begin{array}{l}\text { Pearson \& Munro (1991) } \\
\text { (Michaelmas Reef, GBR) }\end{array}$ & $\begin{array}{c}0.19 \\
(75-382)\end{array}$ & & & \\
\hline $\begin{array}{l}\text { Klumpp et al. (1992) } \\
\text { (Davies Reef, GBR) }\end{array}$ & $\begin{array}{c}0.21 \\
(17-190)\end{array}$ & & & \\
\hline $\begin{array}{l}\text { Gomez \& Mingoa (1993) } \\
\text { (Philippines) }\end{array}$ & $\begin{array}{l}0.26-0.30 \\
(60-150)\end{array}$ & & & \\
\hline OVERALL MEANS & 0.21 & 0.10 & 0.04 & 0.13 \\
\hline
\end{tabular}

weight regressions given in Table 1 . The order of tissue growth rate (in $\mathrm{mg}$ dry wt clam ${ }^{-1} \mathrm{~d}^{-1}$ ) across all size categories was: $T$. gigas $>H$. hippopus $\geq T$. squamosa $>$ $T$. crocea. For growth in shell weight, the order was: $H$. hippopus $>T$. gigas $>T$. squamosa $>T$. crocea. Organic carbon concentration in tissues and shell did not vary significantly between species (ANOVA; $\mathrm{p}<0.05$ ), and averaged $37.7 \%(\mathrm{SE} 1.1, \mathrm{n}=20)$ and $0.30 \%$ (SE $0.02, n=25$ ) of dry weight, respectively.

The total organic carbon deposited daily into tissue plus shell $(G)$ by the 4 size categories of clam, as calculated in Table 8, was highest in Tridacna gigas and lowest in $T$ crocea. Although growth in shell length for $T$. gigas was nearly twice that of Hippopus hippopus (Table 7 ), the difference was actually quite small when expressed as mass (in organic C) of tissue plus shell. This was mainly because $H$. hippopus deposited a comparatively large amount of $\mathrm{C}$ into shell (see below). Using the data in Table 8 , the relationships between growth rate, $G\left(\mathrm{mgC} \mathrm{d}^{-1}\right)$ and clam size ( $W$, in g tissue dry wt) were:

$\begin{array}{ll}\text { T. gigas } & G=4.28 W^{0.68} \\ \text { H. hippopus } & G=3.66 W^{0.67} \\ \text { T. squamosa } & G=2.16 W^{0.73} \\ \text { T. crocea } & G=1.10 W^{071}\end{array}$

Of carbon deposited in tissue and shell, between 10 and $30 \%$ was allocated to shell in the 3 Tridacna species, compared with 30 to $50 \%$ in Hippopus hippopus (Table 8). Although all species show an absolute increase in daily growth, when expressed as a percentage of total tissue carbon growth rates decreased with body size (e.g. from 2.0 to $0.3 \% \mathrm{~d}^{-1}$ in $T$. gigas).

\section{DISCUSSION}

The 4 species of giant clam studied here differ considerably in rates of energy acquisition and expenditure, as expressed in terms of both absolute and relative fluxes of carbon. This is particularly true at the smaller end of the clam size range. For example, in clams of $0.1 \mathrm{~g}$ tissue weight, the combined daily intake 
of carbon from photosynthate and absorbed particles (Table 9) varied more than 10-fold, being greatest in Tridacna gigas $(9.7 \mathrm{mg})$, followed by $T$. crocea (3.7 mg), T. squamosa (1.4 mg) and Hippopus hippopus $(0.7 \mathrm{mg})$. Similarly, the total daily utilisation of carbon for routine respiration plus growth (Table 9) was also highest in $T$. gigas (3.2 mg), followed by $T$. crocea (1.7 $\mathrm{mg}$ ), $T$. squamosa (1.1 $\mathrm{mg}$ ) and $H$. hippopus (0.9 mg). Thus in overall energetic terms, $T$. gigas and $T$. crocea could be classified as exploitative species, with a high rate of energy turnover, compared with the relatively conservative H. hippopus.

Under optimal light conditions, which apply in the present study (shallow/ clear water, cloudless), small Tridacna gigas, $T$. crocea and $T$. squamosa appear to be able to satisfy their growth and respiratory carbon requirements from the combined inputs of photosynthate and ingestion of particulate organic matter (POM), with considerable energy to spare. Any measured surplus of carbon may be accounted for by unrecorded losses (mucus, leaching of amino acids, etc.), and may be counterbalanced in nature when light is reduced under cloudy or turbid conditions (or in deeper water). Alternatively, surpluses may be accounted for by differences between inferred growth rates (from measurements in the field) and those actually occurring in culture (which may have been faster, but were not measured). Moreover, clams in the largest size category of this study $(10 \mathrm{~g}$ for $T$. crocea and $100 \mathrm{~g}$ for others) were close to sexual maturity (Shelley 1989, Pearson \& Munro 1991) and may have utilised surplus energy to lay down reproductive tissue. Energetic costs of reproduction in giant clams are likely to be very significant, based on the report by Shelley \& Southgate (1988) that about $40 \%$ of tissue weight of Hippopus hippopus and $T$. crocea is lost in their one short spawning event. Using our data on tissue carbon content, this equates to a loss of $15 \mathrm{gC}$ for clams of $100 \mathrm{~g}$ tissue weight. Based on the calculated surplus in the daily carbon budget
Table 8. Tridacna spp., Hippopus hippopus. Calculated daily growth in weight of tissue and shell for various species of giant clam. Equivalent shell lengths and shell weights were derived from the length-weight relationships given in Table 1. Average growth in shell length (from Table 7) was then converted to growth in terms of weight of both shell and tissue using the length-weight relationships in Table 1. Organic C contents of shell and tissue (\% dry wt) were 0.30 and 37.7 , respectively

\begin{tabular}{|llrrrr|}
\hline \multirow{2}{*}{ Parameter } & Species & \multicolumn{5}{c}{ Size of clam (g tissue dry wt) } \\
& & 0.1 & 1 & 10 & 100 \\
\hline Equivalent & T. gigas & 42 & 84 & 167 & 331 \\
shell length & T. crocea & 24 & 50 & 101 & $(206)$ \\
(mm) & T. squamosa & 42 & 80 & 150 & 282 \\
& H. hippopus & 40 & 77 & 150 & 291 \\
Equivalent & T. gigas & 5.5 & 46 & 389 & 3281 \\
shell weight & T. crocea & 1.5 & 18 & 224 & $(2718)$ \\
(g) & T. squamosa & 3.8 & 35 & 328 & 3027 \\
& H. hippopus & 12.3 & 92 & 684 & 5101 \\
Daily growth & T. gigas & 1.7 & 8.4 & 41.9 & 212.0 \\
of tissues & T. crocea & 0.5 & 2.5 & 12.5 & $(60.3)$ \\
(mg dry wt) & T. squamosa & 0.9 & 4.6 & 24.3 & 129.2 \\
& H. hippopus & 1.1 & 5.9 & 30.2 & 155.3 \\
Daily growth & T. gigas & 85 & 359 & 1514 & 6470 \\
of shell & T. crocea & 9 & 52 & 310 & $(1852)$ \\
(mg dry wt) & T. squamosa & 32 & 157 & 770 & 3782 \\
& H. hippopus & 123 & 466 & 1799 & 6891 \\
Daily growth of & T. gigas & 0.9 & 4.2 & 20.3 & 99.3 \\
tissues plus shell & T. crocea & 0.2 & 1.1 & 5.6 & $128.3)$ \\
(mg C) & T. squamosa & 0.4 & 2.2 & 11.5 & 60.0 \\
& H. hippopus & 0.8 & 3.6 & 16.8 & 79.2 \\
& & & & & \\
\hline
\end{tabular}

Table 9. Tridacna spp., Hippopus hippopus. Summary of total intake of carbon in the forms of translocated photosynthate $(T P)$ and absorbed particles $(A R)$ compared with total requirements of carbon for host respiration $\left(R_{\mathrm{H}}\right)$ and growth $(G)$. Excess $C$ is shown as the total surplus and that which is available for growth (Scope for Growth)

\begin{tabular}{|c|c|c|c|c|c|}
\hline \multirow{2}{*}{ Parameter } & \multirow{2}{*}{ Species } & \multicolumn{4}{|c|}{ Size of clam (g tissue dry wt) } \\
\hline & & 0.1 & 1 & 10 & 100 \\
\hline \multirow{4}{*}{ 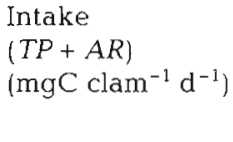 } & T. gigas & 9.7 & 39.2 & 169.7 & 778.2 \\
\hline & T. crocea & 3.7 & 18.2 & 92.1 & $(487.7)$ \\
\hline & T. squamosa & 1.4 & 11.7 & 97.3 & 809.1 \\
\hline & H. hippopus & 0.7 & 5.5 & 57.6 & 675.8 \\
\hline \multirow{4}{*}{$\begin{array}{l}\text { Requirement } \\
\left(R_{\mathrm{H}}+G\right) \\
\left(\mathrm{mgC} \mathrm{clam}^{-1} \mathrm{~d}^{-1}\right)\end{array}$} & T. gigas & 3.2 & 14.7 & 67.0 & 309.6 \\
\hline & T. crocea & 1.7 & 7.1 & 29.2 & $(121.7)$ \\
\hline & T. squamosa & 1.1 & 6.9 & 43.0 & 268.4 \\
\hline & H. hippopus & 0.9 & 4.6 & 30.2 & 258.2 \\
\hline \multirow{4}{*}{$\begin{array}{l}\text { Surplus } \\
\left(\mathrm{mgC} \mathrm{clam}{ }^{-1} \mathrm{~d}^{-1}\right)\end{array}$} & $T$. gigas & 6.5 & 24.5 & 102.7 & 468.6 \\
\hline & T. crocea & 2.0 & 11.1 & 62.9 & $(366.0)$ \\
\hline & T. squamosa & 0.3 & 4.8 & 54.3 & 540.7 \\
\hline & H. hippopus & -0.2 & 0.9 & 27.4 & 417.6 \\
\hline \multirow{4}{*}{$\begin{array}{l}\text { Scope for } \\
\text { Growth } \\
(T P+A R)-R_{\mathrm{H}}\end{array}$} & T. gigas & 7.4 & 28.8 & 123.0 & 567.6 \\
\hline & T. crocea & 2.2 & 12.2 & 68.5 & $(394.3)$ \\
\hline & T. squamosa & 0.7 & 7.0 & 65.8 & 600.7 \\
\hline & H. hippopus & 0.6 & 4.5 & 44.2 & 496.8 \\
\hline
\end{tabular}


of these large clams ( 0.4 to $0.5 \mathrm{gC}_{i}$ Table 9), we estimate that the carbon lost on spawning would be replaced in 30 to $40 \mathrm{~d}$. This energy expenditure would also be compensated, to some unknown extent, by the reduction in growth rate which is known to accompany the onset of sexual maturity (Lucas in press).

According to our calculations, small individuals of Hippopus hippopus $(0.1 \mathrm{~g})$ are unable to derive sufficient carbon from the combined intake of POM and photosynthates to satisfy their growth and respiration requirements (Table 9). This energy shortfall may be made up from other sources of nutrition. Two potential sources of such nutrition are dissolved organic matter (DOM; Goreau et al. 1973, Fitt 1993b, Lucas in press). and the digestion of zooxanthellae (Fankboner 1971, Reid et al. 1984), although neither process has been well quantified in clams. To date, Goreau et al. (1973) has provided the only quantification of DOM uptake by showing incorporation of a labelled amino acid into the mantle and gill tissues of Tridacna maxima. Recently, Hawkins \& Klumpp (in press) demonstrated that ingestion of POM and the symbiotic association with zooxanthellae contributed $70 \%$ of the nitrogen requirements of $T$. gigas, and they suggested that the shortfall was most likely to be provided through the uptake of DOM. The large mantle and highly convoluted gill morphology of giant clams would facilitate the active uptake of DOM. Certainly small clams, with their comparatively high surface-area-to-volume ratio, would be best adapted for DOM uptake, and the role of this process in clam nutrition warrants further investigation. Digestion of zooxanthellae by the host seems to be discounted by recent research (Fitt et al. 1986). Moreover, any sustained gain in energy to the host from zooxanthellae is basically accounted for in the estimation of overall photosynthetic production (i.e. TP).

The 4 clam species are further distinguished from each other by differences in the absolute and relative nutritional contributions to the host of the 2 sources of carbon examined here, namely photosynthate (Figs. 1 \& 4) and POM (Table 5, Fig. 4), and in the partitioning of this carbon between growth (Table 8 ) and respiration (Table 4). This study confirms the established view that phototrophy is a vital component of giant clam energetics, but takes this a step further by quantifying the significant energetic cost to the host of growth in tissues and shell. All species and sizes of clam in this study (except for small Hippopus hippopus) obtain sufficient carbon solely from phototrophic sources to satisfy not only their routine respiratory needs (i.e. the CZAR value), but also the additional demand for carbon deposited into tissues and shell (Table 9). Previous studies have shown that when $\% T$ values of $95 \%$ are used CZAR values are well above $100 \%$ for Tridacna gigas (Fisher et al. 1985, Mingoa 1988, Klumpp et al.

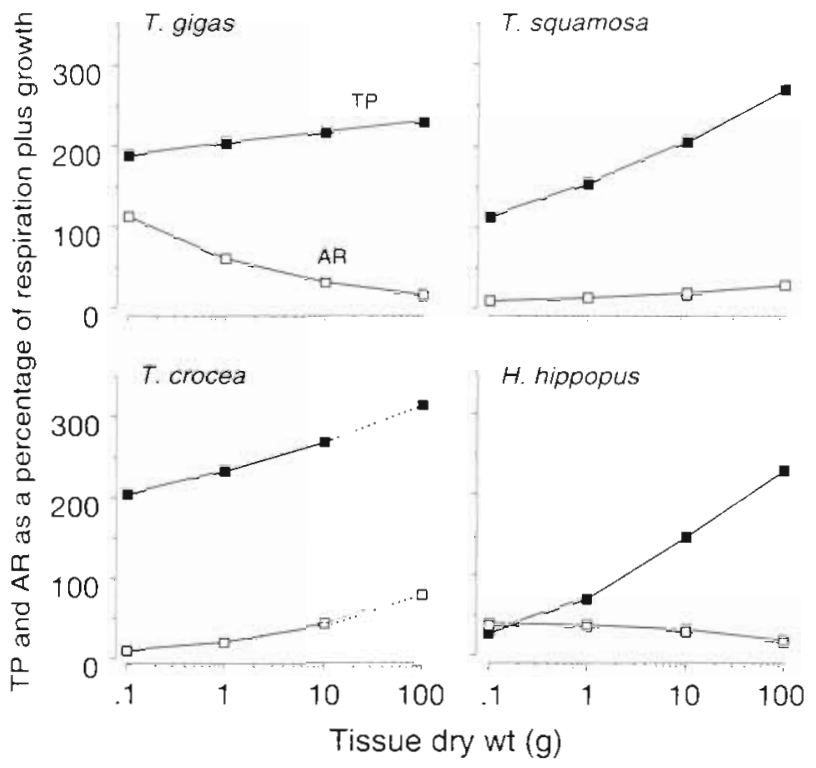

Fig. 4. Tridacna spp., Hippopus hippopus. The percent contribution of translocated photosynthates (TP) and absorbed ration $(A R)$ to respiration plus growth as a function of size (tissue dry wt) in the 4 species of clam

1992), T. derasa, T. tevoroa (Klumpp \& Lucas 1994) and T. maxima (Trench et al. 1981).

The relative contribution of photosynthates (TP) to energy requirements of clams increases significantly with clam size in all 4 species in this study, but this is most marked in Hippopus hippopus and T. squamosa (Fig. 4). Phototrophic contribution also increases with size in $T$. tevoroa and $T$. derasa in Tongan waters (Klumpp \& Lucas 1994). It is known that giant clam larvae are dependent on exogenous sources of food (Southgate 1988, 1993), and that zooxanthellae numbers increase exponentially with shell length in juvenile $T$. gigas (Fitt et al. 1993) hence providing an increasing proportion of total nutrition. The precise relationships between phototrophic capacity, zooxanthellae density, and mantle area as a function of clam size in $T$. gigas, $T$. crocea, $T$. squamosa and $H$. hippopus will be described in a related study (Griffiths \& Klumpp unpubl.).

The capacity for typical lamellibranch filter feeding in giant clams has been recognised for some time (Yonge 1936), but the nutritional significance of this has only recently been quantified. Ingestion and digestion of $\mathrm{C}^{14}$-labelled phytoplankton cells by Tridacna gigas was demonstrated by Fitt et al. (1986). Klumpp et al. (1992) showed that $T$. gigas is an efficient filter feeder, capable of retaining most particles between 2 and $50 \mu \mathrm{m}$, and in the process absorbing about half of the ingested POM. They calculated that POM was a significant energy source to juvenile clams, providing $65 \%$ of carbon needs to small individuals $(0.1 \mathrm{~g}$ dry 
tissue) living at $5 \mathrm{~m}$ depth on offshore coral reefs (POM at $97 \mu \mathrm{gC} \mathrm{l}^{-1}$ ). POM is also a very important source of nitrogen to these clams (Hawkins \& Klumpp in press). The dependence of clams on POM as an energy (and N) source declined with clam size due to the differing allometric relationships describing the processes of phototrophic and exogenous energy intake and energy metabolism (Klumpp et al. 1992).

The same general pattern in the relationship between filter feeding and size is seen for Tridacna gigas and Hippopus hippopus in this study. In simulated shallow inshore reef environment (POM at $200 \mu \mathrm{gC}$ $\left.1^{-1}\right)$, POM can provide $113 \%$ of the total carbon requirements of small $T$. gigas $(0.1 \mathrm{~g})$, but this contribution diminishes to only $18 \%$ in $100 \mathrm{~g}$ clams (Fig. 4). POM also provides a high proportion $(45 \%)$ of the carbon requirements of the smallest $H$. hippopus. This is additionally significant since photosynthates only provide $34 \%$ of the growth and respiratory requirements of these clams. It is interesting to note that Shelley (1989) speculated that $H$. hippopus might have enhanced dependence on filter feeding based on his observations that it possesses a large kidney compared with other giant clams. He also noted that this species had a restricted mantle area, which is consistent with its low photosynthetic performance (in small individuals; see above \& Table 4). T. crocea and T. squamosa present a different pattern in that POM contributes only about $10 \%$ to the requirements of small clams, although this contribution increases with size. Filter feeding also played only a minor role ( 8 to $14 \%$ of needs) as an energy source to $T$. derasa and $T$. tevoroa from reefs in Tonga (Klumpp \& Lucas 1994). These clams were able to rely entirely on phototrophy for their energy needs (except in the case of populations in waters $>15 \mathrm{~m}$ ).

There are inter-specific differences in the partitioning by clams of known total carbon expenditure between respiration $\left(R_{H}\right)$ and growth (Tables $4,8 \& 9$ ). For example, at one extreme Tridacna crocea allocates from. $10 \%$ (small clams) to $20 \%$ (large clams) of total carbon expenditure to growth, compared with 90 to $30 \%$, respectively, in Hippopus hippopus. $T$. gigas and $T$. squamosa both allocate between 20 and $40 \%$ of their energy expenditure to growth, as do $T$. tevoroa and T. derasa in Tongan waters (Klumpp \& Lucas 1994). Klumpp et al. (1992) recorded proportionally higher deposition to growth for $T$. gigas on offshore reefs of the GBR ( 38 to $45 \%$ ), since respiration rates were much lower in the winter when this study was conducted. Thus, as a group, giant clams (through having access to phototrophic and heterotrophic nutritionj are able to allocate a higher proportion of their energy expenditure to growth compared with non-symbiotic bivalve molluscs (max. 25\%; Bayne \& Newell 1983).
The original aim of the present study was to assess the nutritional basis of the large differences in growth rates (and maximum sizes) of the 4 clam species. Our results show that calculation of the net carbon (energy) available for growth fails to provide a complete explanation for these differences. Certainly the fastestgrowing and largest species, Tridacna gigas, has a considerable nutritional advantage and the greatest 'scope' for growth (Table 9). However, it appears that availability of $\mathrm{C}$ is not limiting to growth in $T$. croced, the smallest and slowest-growing of the species. T. gigas and $T$. crocea both appear to have an order of magnitude more $\mathrm{C}$ available than is required for growth. Growth rate in $T$. crocea may be limited firstly by the physical constraints of its habit of burrowing into coral rock (Hamner \& Jones 1976), and by the (unmeasured) expenditure of energy on the expansion of the burrow as it grows. Small individuals of $T$. squamosa $(0.1 \mathrm{~g})$ grow at about half the rate of $T$. gigas (in terms of both shell length and mass), and are also more limited in the amounts of $\mathrm{C}$ available for growth. In the case of Hippopus hippopus, growth in length is half that of T. gigas, but when growth is converted to mass, the differences between these species is only slight. However, a relatively high proportion of growth in $H$. hippopus is in the form of shell. Growth in small H. hippopus $(0.1$ to $1.0 \mathrm{~g})$ seems limited by the combined supply of energy from POM and photosynthates (see above). Under the optimal conditions of particulate food supply and irradiance used in our experiments, growth of larger clams $(>1 \mathrm{~g}$ ) of all 4 species does not appear to be limited by $C$ supply to the host (Tables $8 \& 9$ ). However, reductions in irradiance under natural conditions, such as would be caused by increased turbidity and cloudiness, may reduce 'scope' for growth down to limiting levels. A quantitative assessment of this requires further work on the capacity of giant clams to photoadapt to variations in irradiance (Klumpp et al. 1992, Klumpp \& Lucas 1994).

While these data explain why Tridacna gigas juveniles grow so rapidly at an early stage, they do not provide any answer as to why $T$. gigas grow to be so much larger than T. squamosa and Hippopus hippopus. In the largest clam-size category, the 'scope' for growth of $T$. gigas is similar to that of the other species, yet this clam goes on to grow to typically $700 \mathrm{~mm}$, or more, after other species have reached a maximum at $400 \mathrm{~mm}$ (refer 'Introduction'). One reason for this difference may be that $T$. gigas delays the onset of sexual maturity compared to the other species, and thus, continues to put energy into growth that the other species are diverting into gamete production. Giant clams first mature as males, and although gametes may be released during this phase, the energetic costs are likely to be low due to the small relative size of the 
testes (Lucas pers comm.). Large investment of energy into reproduction comes with female maturity (see above), and this is reached at about 4 yr of age in the 'medium-sized' tridacnids such as $H$. hippopus and T. squamosa (Jameson 1976, Shelley \& Southgate 1989 Lucas in press). In contrast, $T$. gigas cultured on the GBR attained male maturity after $6 \mathrm{yr}$, but had yet to reach female maturity after 8 yr at which time the specimens were ca $500 \mathrm{~mm}$ SL (Lucas unpubl.).

In conclusion, this study has demonstrated that there are distinct differences between the nutritional capabilities of various species of giant clam. These differences were evident in terms of both the absolute and relative amounts of carbon supplied to the host via photosynthesis and filter feeding, as well as the utilisation of this carbon in growth and metabolism. Such differences do not provide a simple explanation for the significant differences between growth rates of the 4 giant clam species, mainly because energy availability is generally not limiting to growth under the particular environmental conditions of this study. Nevertheless, we have shown that the largest and fastest-growing species is nutritionally the most efficient, and has by far the greatest 'scope' for growth when small $(<100 \mathrm{~g})$. This stems from its ability to utilise effectively the sources of energy available from both the symbiotic association and the filtering of POM. These results have also confirmed that phototrophy is the most significant source of energy to the host across a range of sizes and species of giant clams, while filter feeding is very important in the nutrition of small individuals (20 to $100 \mathrm{~mm}$ ) of at least 2 species (Tridacna gigas and Hippopus hippopus). If these results can be extrapolated down to very small clams, they would indicate that POM is a critical food resource to all giant clam species.

Further research is needed on the energetics of very small clams. The potential role of DOM in satisfying the clam's metabolic and growth requirements should also be investigated. On the other hand we know little of the nutritional aspects of reproductive development in large clams and the associated changes in somatic tissue production, and of the mechanisms which permit Tridacna gigas to continue to grow well beyond the maximum size of any other tridacnid. In order to better understand the nutritional roles of phototrophy and heterotrophy in natural populations of giant clams, it will be necessary to simulate the effects on their energy budgets of varying quantity and quality of particulates, and the availability of light.

Acknowledgements. We thank John Lucas of James Cook University for his continued encouragement and helpful discussions throughout this project, including comments on the draft manuscript, and for providing some of the clam speci- mens used in this study. We are also most grateful to David McKinnon and Sheryl Fitzpatrick of AIMS for their assistance with chemical and data analyses and preparation of figures. CLG thanks the University of Cape Town, the Foundation for Research Development and Vera Davie Bursary Fund for supportıng his sabbatical in Australia. AIMS contribution no. 710

\section{LITERATURE CITED}

Barker, J. R., Lucas, J. S., Nash, W. J. (1988). Comparative growth rates for Tridacna gigas at different locations in north-eastern Australia. In: Copland, J. W., Lucas, J. S. (eds.) Giant clams in Asia and the Pacific. ACIAR Monograph No. 9, Australian Centre for International Agricultural Research, Canberra, p. 145-150

Bayne, B. L., Newell, R. C. (1983). Physiological energetics of marine molluscs. In: The Mollusca, Vol. 4. Academic Press, London, p. 407-515

Beckvar, N. (1981). Cultivation, spawning and growth of the giant clams Tridacna gigas, Tridacna derasa and Tridacna squamosa in Palau, Caroline Islands. Aquaculture 24 : $21-30$

Bonham, K. (1965). Growth rate of the giant clam Tridacna gigas at Bikini Atoll as revealed by radioautography. Science 149: 300-302

Chalker, B. E. (1981). Simulating light-saturation curves for photosynthesis and calcification by reef-building corals. Mar. Biol. 63: 135-141

Conover, R. J. (1966). Assimilation of organic matter by zooplankton. Limnol. Oceanogr. 18: 673-678

Crawford, C. M., Lucas, J. S., Nash, W. J. (1988). Growth and survival during ocean-nursery rearing of giant clams, Tridacna gigas. Assessment of four culture methods. Aquaculture 68: 103-113

Crossland, C. J. Barnes, D. J. (1983). Dissolved nutrients and organic particulates in water flowing over coral reefs at Lizard Island. Aust. J. mar Freshwat. Res. 34: 834-844

Davies, P. S. (1991). Effects of daylight variation on energy budgets of shallow water corals. Mar. Biol. 108: 137-144

Fankboner, P. V. (1971). Intracellular digestion of symbiotic zooxanthellae by host amoebocytes in giant clams (Bivalvia: Tridacnidae), with a note on the role of the hypertrophied siphonal epidermis. Biol. Bull 141: 222-234

Fisher, C. R., Fitt, W. K., Trench, R. K. (1985). Photosynthesis and respiration in Tridacna gigas as a function of irradiance and size. Biol. Bull. 169: 230-245

Fitt, W. K. (1993a). Biology and mariculture of giant clams. ACIAR Proceedings No. 47, Australian Centre for International Agricultural Research, Canberra

Fitt, W. K. (1993b). Nutrition of giant clams. In: Fitt, W. K. (ed.) Biology and mariculture of giant clams. ACIAR Proceedings No. 47, Australian Centre for International Agricultural Research, Canberra, p. 31-40

Fitt, W. K., Fisher, C. R., Trench, R. K. (1986). Contribution of the symbiotic dinoflagellate Symbiodinium microadriaticum to the nutrition, growth and survival of larval and juvenile tridacnid clams. Aquaculture 55: 5-22

Fitt, W. K., Rees, T. A. V., Braley, R. D., Lucas, J. S., Yellowlees, D. (1993). Nitrogen flux in giant clams: size-dependency and relationship to zooxanthellae density and clam biomass in the uptake of dissolved inorganic nitrogen. Mar. Biol. 117: $381-386$

Gattuso, J.-P., Yellowlees, D., Lesser, M. (1993). Depth- and light-dependent variation of carbon partitioning and utilization in the zooxanthellate scleractinian coral Stylophora pistillata. Mar. Ecol. Prog. Ser. 92: 267-276 
Gomez, E. D., Belda, C. A. (1988). Growth of giant clams in Bolinao, Philippines. In: Copland, J. W., Lucas, J. S. (eds.) Giant clams in Asia and the Pacific. ACIAR Monograph No. 9, Australian Centre for International Agricultural Research, Canberra, p. 178-182

Gomez, E. D., Mingoa, S. S. M. (1993). Tridacna gigas and T derasa: a growth comparison. In: Fitt, W. K. (ed.) Biology and mariculture of giant clams. ACIAR Proceedings No. 47. Australian Centre for International Agricultural Research, Canberra, p. 74-81

Goreau, T. F., Goreau, N. I., Yonge, C. M. (1973). On the utilisation of photosynthetic products from zooxanthellae and of a dissolved amino acid in Tridacna maxima f elongata (Mollusca: Bivalvia). J. Zool., Lond. 169: 417-454

Griffiths, D. J., Streamer, M. (1988). Contribution of zooxanthellae to their giant clam host. In: Copland, J. W., Lucas, J. S. (eds.) Giant clams in Asia and the Pacific. ACIAR Monograph No. 9, Australian Centre for International Agricultural Research, Canberra, p. 237-252

Hamner, W. M., Jones, M. S. (1976). Distribution, burrowing, and growth rates of the clam Tridacna crocea on interior reef flats. Oecologia 24: $207-227$

Hawkins, A. J. S., Klumpp, D. W. (in press). Nutrition of the giant clam Tridacna gigas (L.). II. Relative contributions of filter-feeding and the ammonium-nitrogen acquired and recycled by symbiotic alga towards their total nitrogen requirements for tissue growth and metabolism. J. exp. mar. Biol. Ecol.

Hildreth, D. I., Crisp, D. J. (1976). A corrected formula for calculation of filtration rate of bivalve molluscs in an experimental flowing system. J. mar. biol. Ass. U.K. 56: 111-120

Jameson, S. C. (1976). Early life history of the giant clams Tridacna crocea Lamarck, Tridacna maxima (Roding), and Hippopus hippopus (Linnaeus). Pacif. Sci. 30: 219-233

Klumpp, D. W., Bayne, B. L., Hawkins, A. J. S. (1992). Nutrition of the giant clam Tridacna gigas (L.). 1. Contribution of filter feeding and photosynthates to respiration and growth. J. exp. mar. Biol. Ecol. 155: 105-122

Klumpp, D. W., Lucas, J. S. (1994). Nutritional ecology of the giant clams Tridacna tevoroa and $T$. derasa from Tonga: influence of light on filter-feeding and photosynthesis. Mar. Ecol. Prog. Ser. 107 147-156

Klumpp, D. W., McKinnon, D., Daniel, P. (1987). Damselfish territories: zones of high productivity on coral reefs. Mar. Ecol. Prog. Ser. 40: 41-51

Lucas, J. S. (1988). Giant clams: description, distribution and life history. In: Copland, J. W., Lucas, J. S. (eds.) Giant clams in Asia and the Pacific. ACIAR Monograph No. 9, Australian Centre for International Agricultural Research, Canberra, p. 21-32

Lucas, J. S. (in press). The biology, exploitation, and mariculture of giant clams (Tridacnidae). Rev. Fish. Sci.

Mingoa, S. M. (1988). Photoadaptation in juvenile Tridacna gigas. In: Copland, J. W., Lucas, J. S. (eds.) Giant clams in Asia and the Pacific. ACIAR Monograph No. 9, Australian Centre for International Agricultural Research, Canberra, p. $145-150$

Munro, J. L., Heslinga, G. A. (1983). Prospects for the com- mercial cultivation of giant clams (Bivalvia: Tridacnidae). Proc. Gulf Caribb. Fish. Inst. 35: 122-134

Murakoshi, M. (1986). Farming of the boring clam, Tridacna crocea Lamarck. Galaxea 5: 239-254

Muscatine, L. (1990). The role of symbiotic algae in carbon and energy flux in reef corals. In: Dubinsky, Z. (ed.) Coral reefs. Elsevier, Amsterdam, p. 75-87

Muscatine, L., McCloskey, L. R., Marian, R. E. (1981). Estimating the daily contribution of carbon from zooxanthellae to coral animal respiration. Limnol. Oceanogr. 26: $601-611$

Pearson, R. G., Munro, J. L. (1991). Growth, mortality and recruitment rates of giant clams, Tridacna gigas and $T$ derasa, at Michaelmas Reef, central Great Barrier Reef, Australia. Aust. J. mar. Freshwat Res. 42: 241-262

Reid, R. G. B., Fankboner, P. V., Brand, D. G. (1984). Studies on the physiology of the giant clam Tridacna gigas Linne. II. Kidney function. Comp. Biochem. Physiol. 78A: 95-101

Sandstrom, M. W., Tirendi, F., Nott, A. (1986). Direct determination of organic carbon in modern reef sediments and calcareous organisms after dissolution of carbonate. Mar. Geol. 70: 321-329

SAS (1985). SAS users guide: statistics, Version 5 edition. SAS Institute Inc., Cary, NC

Shelley, C. C. (1989). Growth, sclerochronology and development of the Tridacnidae, with particular reference to Hippopus hippopus. Ph.D. thesis, James Cook University of North Queensland

Shelley, C. C., Southgate, P. C. (1988). Reproductive periodicity and morphology of Hippopus hippopus and Tridacna crocea. In: Copland, J. W., Lucas, J. S. (eds.) Giant clams in Asia and the Pacific. ACIAR Monograph No. 9, Australian Centre for International Agricultural Research, Canberra, p. $86-88$

Solis, E. P., Onate, J. A., Naguit, M. R. A. (1988). Growth rates of Hippopus hippopus from Orpheus lsland, Great Barrier Reef. In: Copland, J. W., Lucas, J. S. (eds.) Giant clams in Asia and the Pacific. AClAR Monograph No. 9, Australian Centre for International Agricultural Research, Canberra, p. 201-206

Southgate, P. C. (1988). Biochemical development and energetics of Hippopus hippopus larvae. In: Copland, J. W., Lucas, J. S. (eds.) Giant clams in Asia and the Pacific. ACIAR Monograph No. 9, Australian Centre for International Agricultural Research, Canberra, p. 140-144

Southgate, P. C. (1993). Growth and survival of Tridacna gigas larvae: the role of exogenous nutrition. In: Fitt, W. K. (ed.) Biology and mariculture of giant clams. ACIAR Proceedings No. 47, Australian Centre for International Agricultural Research, Canberra, p. 46-49

Trench, R. K. (1979). The cell biology of plant-animal symbiosis. Ann. Rev. Plant Physiol. 30: 485-531

Trench, R. K., Wethey, D. S., Porter, J. W. (1981). Observations on the symbiosis with zooxanthellae among the Tridacnidae (Mollusca, Bivalvia). Biol. Bull. 161: 180-198

Yonge, C. M. (1936). Mode of life, feeding, digestion and symbiosis with zooxanthellae in the Tridacnidae. Sci. Rep. Great Barrier Reef Exp. 1: 283-321

Manuscript first received: April 5, 1994

Revised version accepted: August 31, 1994

This article was submitted to the editor 